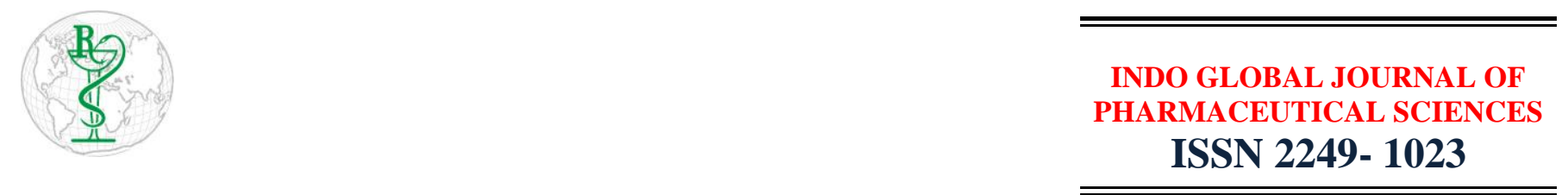

\title{
Oral delivery of Insulin: A Novel Approaches for Diabetes Patients
}

\author{
Mandeep Singh *, Sachin Sharma, Dinesh Kumar \\ Sri Sai College of Pharmacy, Manawala, Amritsar-143115, Punjab, India \\ Address for Correspondence: Mandeep Singh; mandeep07599@gmail.com
}

Received:
01.03.2019
Accepted:
25.03.2019
Keywords
Metabolic
Disorders;
Diabetes
mellitus; Insulin
Therapy.

Received:

Accepted:

Keywords

Metabolic

Disorders;

mellitus; Insulin

Therapy.

\begin{abstract}
Diabetes mellitus is a major pathologic condition which is responsible for the major healthcare problem in worldwide. The insulin is the commonly used for the treatment of the diabetes which given through intravenous and other route. Oral insulin is a dream of patients and a challenge for scientists. There are some obstructions that are faced during the oral delivery of Insulin i.e. Extreme $\mathrm{pH}$ conditions and proteolytic enzymes, Intestinal epithelium, efficient transport along GI tract etc. These condition not helpful for the absorption of insulin in gastrointestinal up to the systemic circulation. The bioavailability of insulin by oral route may be enhanced by modification in physiological properties, use of improved carrier system. The use of liposomes, microencapsulation, the use of other carrier system may help to achieve the bioavailability of insulin up to 50 percent. The new advancement in the nanoparticles and carrier system may help in the absorption and bioavailability of the insulin. Some polymeric modifications also help in the oral absorption of insulin. The oral route helps to reduce the major problems which are faced during the administration of insulin by other route. () 2019 iGlobal Research and Publishing Foundation. All rights reserved.
\end{abstract}

Cite this article as: Singh, M.; Sharma, S.; Kumar, D. Oral Delivery of Insulin: A Novel Approaches for Diabetes Patients. Indo Global J. Pharm. Sci., 2019; 9(2Suppl.): 151 . DOI: http://doi.org/10.35652/IGJPS.2019.92S49.

Indo Global Journal of Pharmaceutical Sciences( ISSN 2249 1023; CODEN- IGJPAI; NLM ID: 101610675) indexed and abstracted in CrossRef (DOI Enabling), UGC CARE Journal List, EMBASE(Elsevier), National Library of Medicine (NLM) Catalog, ResearchGate, Publons, CAS (ACS), Index Copernicus, Google Scholar and many more. For further details, visit http://iglobaljournal.com

This is a special issue as an outcome of 'RAPSCON-2019' sponsored by APTI and organized by Sri Sai College of Pharmacy, Manawala, Amritsar, Punjab, India. Relaxation offered in journal format. 